\title{
$\frac{100}{\text { LAT }}$ RPEiS
}

\section{SAMODZIELNOŚĆ PRAWOTWÓRCZA JEDNOSTEK SAMORZĄDU TERYTORIALNEGO}

\section{WSTĘP}

Prawo miejscowe zajmuje w polskim porządku prawnym bardzo ważne miejsce. Wiąże zarówno obywateli - mieszkańców danego obszaru, jak i organy administracji publicznej. Jednak samodzielność prawotwórcza organów jednostek samorządu terytorialnego nie ma charakteru nieograniczonego. Organ uchwałodawczy, tworzac prawo miejscowe, musi działać na podstawie przepisów prawa, w granicach swoich kompetencji oraz delegacji ustawowych (wskazywać każdorazowo podstawę prawna). Musi nie tylko trzymać się ram delegacji, lecz także brać pod uwagę również treść i założenia ustawy stanowiącej tę delegację. $\mathrm{Z}$ art. 87 Konstytucji $\mathrm{RP}^{1}$ wynika uporządkowany hierarchicznie system źródeł, w którym prawo miejscowe zajmuje ostatnie miejsce, co przy założeniu, że lokalny prawodawca ma dużą swobodę działania, zapewnia jednak spójność i jednolitość krajowego porządku prawnego.

Ustawodawca przyznał organom samorządu terytorialnego dużą samodzielność prawotwórczą. Jej źródeł można doszukać się już w Konstytucji RP (m.in. zasada ochrony sądowej samodzielności, zasada decentralizacji, zasada subsydiarności, zasada podziału władz, zasada zwierzchnictwa narodu), a w następnej kolejności w samorządowych ustawach ustrojowych ${ }^{2}$. Unormowania te są dodatkowo wzmocnione przez przepisy Europejskiej karty samorządu lokalnego ${ }^{3}$, stanowiące o prawie społeczności lokalnych do pełnej swobody działania

* Joanna Podgórska-Rykała, Uniwersytet Pedagogiczny im. Komisji Edukacji Narodowej w Krakowie, joanna.podgorska-rykala@up.krakow.pl, https://orcid.org/0000-0002-5723-0363

${ }^{1}$ Konstytucja Rzeczpospolitej Polskiej z 2 kwietnia 1997 r. (Dz. U. Nr 78, poz. 483 ze zm.)

${ }^{2}$ Ustawa o samorządzie gminnym z 8 marca 1990 r., t.jedn.: z 22 lutego 2019 r., Dz. U. 2019, poz. 506 (dalej jako: u.s.g.); ustawa o samorządzie powiatowym z 5 czerwca 1998 r., t.jedn.: z 22 lutego 2019 r., Dz. U. 2019, poz. 511 (dalej jako: u.s.p.); ustawa o samorządzie województwa z 5 czerwca 1998 r., t.jedn.: z 22 lutego 2019 r., Dz. U. 2019, poz. 512.

${ }^{3}$ Europejska karta samorządu lokalnego sporządzona w Strasburgu dnia 15 października 1985 r., Dz. U. 1994, Nr 124, poz. 607 ze zm. (dalej jako: EKSL). 
na swoim terytorium, oczywiście z poszanowaniem zasady legalizmu. Przypisanie przymiotu samodzielności jednostkom samorządowym zostało utrwalone również w orzecznictwie, m.in. za sprawą uchwały Trybunału Konstytucyjnego (TK) z 1994 r., w której podkreśla się wielokrotnie, iż: ,jednostki samorządu terytorialnego wykonując zadania publiczne [...] uczestniczą w sprawowaniu władzy [...], ale czynią to na szczególnych zasadach, z których najważniejsze znaczenie ma zasada prawem przyznanej i prawem chronionej samodzielności"4. Co prawda przywołana uchwała datowana jest na okres poprzedzający wejście w życie obowiązującej Konstytucji RP (1997) i jest obecnie z tej przyczyny uchylona, ale linia orzecznicza TK pozostała niezmieniona. Z samą istota samodzielności mamy do czynienia w wielu dziedzinach działalności samorządów, jednak prawodawstwo wydaje się jedna z najistotniejszych ${ }^{5}$. Akty prawne wyznaczaja bowiem normy i reguły postępowania, gdyż wiążą określone grupy adresatów i wpływają na ich sytuację podmiotowa.

Prawo miejscowe odgrywa coraz większą rolę w kształtowaniu praw podmiotowych obywateli, jako że stwarza podstawy działania organów administracji publicznej, w tym także władczego. Z uwagi na systematycznie rosnący zasięg miejscowych regulacji i ich bezpośredni wpływ na podmiotowe prawa i obowiązki mieszkańców prawo tworzone przez polskie samorządy staje się w coraz większym stopniu fundamentem codziennego kształtowania sytuacji prawnej jednostki. Wynikające $\mathrm{z}$ tego zwiększenie zainteresowania prawem miejscowym przez ustawodawcę, jak i samych adresatów norm prawnych, stanowi wyraz ich dążenia do podniesienia jakości przyjmowanych w jednostkach samorządu terytorialnego rozwiązań i rozstrzygnięć.

Celem artykułu jest ukazanie istoty samodzielności prawotwórczej jednostek samorządu terytorialnego, scharakteryzowanie poszczególnych form prawnych, które przybierają ich decyzje, oraz wyodrębnienie i zdefiniowanie - posługując się dorobkiem doktryny i orzecznictwem - poszczególnych kategorii aktów tworzonych przez organy samorządowe. Na treść rozważań składają się, zarówno uwagi teoretycznoprawne, jak i związane z praktyka funkcjonowania badanych przepisów prawa. W artykule posłużono się metodami charakterystycznymi studiów z prawa i administracji. Narzędziem głównym jest analiza aktów prawnych, a narzędziem pomocniczym - funkcjonalna analiza systemowa.

\section{PODSTAWA PRAWNA STANOWIENIA AKTÓW PRAWA MIEJSCOWEGO}

Samorządowe akty prawa miejscowego sa stanowione na podstawie przepisów Konstytucji RP, samorządowych ustaw ustrojowych oraz innych ustaw, stanowiących obszerny zbiór prawa materialnego. Wyróżnia się trzy rodzaje

\footnotetext{
${ }^{4}$ Uchwała TK z 27 września 1994 r. w sprawie ustalenia powszechnie obowiązującej wykładni art. 85 i art. 87 ustawy z 8 marca 1990 r. o samorządzie terytorialnym, Dz. U. 1994, Nr 113, poz. 550 .

${ }^{5}$ Por. wyrok NSA z 4 lutego 2014 r., II OSK 2915/13.
} 
takich aktów. Po pierwsze, o charakterze wykonawczym, które wydawane sa na podstawie szczegółowych upoważnień zawartych w ustawach administracyjnego prawa materialnego. Wydaje się je w celu szczegółowej realizacji założeń materialnoprawnych wynikających z konkretnych ustaw.

Po drugie, o charakterze ustrojowoorganizacyjnym (strukturalno-organizacyjne), które wydawane sa na podstawie upoważnień generalnych zawartych w samorządowych ustawach ustrojowych. Są to akty regulujace m.in. wewnętrzny ustrój jednostki, organizację działania urzędów i instytucji, zasady zarządu mieniem oraz zasady i tryb korzystania z obiektów i urządzeń użyteczności publicznej. Najważniejszymi aktami tego rodzaju są statuty. Różnia się od innych aktów prawa miejscowego nie forma, a treścia, regulują bowiem bardzo istotna - z punktu widzenia danej wspólnoty samorządowej - materię ${ }^{6}$ W tym miejscu należy zatrzymać się na chwilę i doprecyzować, że w myśl art. 169 ust. 4 Konstytucji RP ustrój wewnętrzny jednostek samorządu terytorialnego określaja, w granicach ustaw, ich organy stanowiące i na mocy przepisów samorządowych ustaw ustrojowych dzieje się to właśnie w statucie, który jest aktem prawnym o charakterze normatywnym ${ }^{7}$. W doktrynie porównuje się statuty jednostek samorządu terytorialnego do lokalnych konstytucji. Dlatego też zasadniczo statuty stanowią akty stałe, a nie uchwalane czasowo, na jedną kadencję. Istota statutu wpisuje się w przepisy art. 6 ust. 1 EKSL, zgodnie z którym, jeśli bardziej ogólne postanowienia ustawy nie stanowią inaczej, społeczności lokalne powinny móc samodzielnie ustalać swą wewnętrzna strukturę administracyjna, tworząc jednostki dostosowane do specyficznych potrzeb i umożliwiajace skuteczne zarządzanie. Warto jednak podkreślić, że w praktyce stosowania prawa zdarza się, że mylnie utożsamia się ustrój jednostki samorządu terytorialnego uregulowany w statucie z organizacją wewnętrzną oraz trybem pracy jej organów. Jest to nieuzasadnione zawężenie materii statutowej.

Po trzecie, można wyróżnić akty o charakterze porządkowym. Wydawane są one na podstawie upoważnień generalnych zawartych w ustawach ustrojowych. Mają charakter nadzwyczajny, a przesłanka ich wydania jest istnienie nieuregulowanego ustawami lub innymi aktami prawa zakresu spraw. Wydaje się je m.in. wówczas, gdy jest to niezbędne dla ochrony życia lub zdrowia obywateli oraz dla zapewnienia porządku, spokoju i bezpieczeństwa publicznego ${ }^{8}$. Trzy wskazane grupy aktów prawa miejscowego różnią się od siebie zasadniczo, szczególnie jeśli chodzi o ich podstawy prawne i wynikająca z nich swobodę (mniejszą lub większa) w zakresie kształtowania treści, ale też trybu ich wydawania czy możliwych sankcji za niestosowanie się do nich, a nawet wywoływanych skutków ${ }^{9}$. Mimo że wszystkie akty prawa miejscowego maja sensu largo charakter wykonawczy, ponieważ stanowione są w granicach upoważnienia ustawowego ${ }^{10}$, to jednak ich charakter prawny jest zróżnicowa-

\footnotetext{
${ }_{6}$ Nowacka (1997): 70-72.

7 Wyrok NSA z 9 marca 1999 r., II SA 5/99.

8 Kotulski (2001): 36-40.

9 Dolnicki (2018a): 299.

10 Dąbek (2003): 76-77.
} 
ny. Z tego względu można je sklasyfikować zgodnie z rozmaitymi kryteriami (m.in.: rodzaj upoważnienia ustawowego, kryterium podmiotowe, kryterium przedmiotowe i inne $)^{11}$.

\section{PROBLEMY ZE ZDEFINIOWANIEM AKTÓW PRAWA MIEJSCOWEGO}

Mimo że w Konstytucji RP w art. 94 zawarto ogólną charakterystykę aktów prawa miejscowego, w doktrynie podnosi się, iż nie jest to ujęcie wystarczające i w żadnym razie nie stanowi jednoznacznej ich definicji. Określenie, która uchwała jest, a która nie, aktem prawa miejscowego, komplikuje więc fakt, iż nie tylko w ustawie zasadniczej, ale również w żadnej innej ustawie nie dokonano precyzyjnego zdefiniowania takiego aktu. Dlatego też w nauce prawa administracyjnego brakuje jednolitości w tym zakresie, a chęć jednoznacznego ustalenia, czym w istocie jest akt prawa miejscowego, pozostawia pole do odmiennych interpretacji, „które przy różnych okazjach znajdują swoje rozstrzygnięcia w sądach administracyjnych"12. Stanisław Bułajewski zauważa, że „termin ten od wielu lat budzi wiele kontrowersji i niejasności, ponieważ nie jest jednoznaczny. O niejednoznaczności kategorii aktów prawa miejscowego wypowiadał się też wielokrotnie TK. W swoim postanowieniu z 6 października 2004 r. stwierdził, że „samo nazwanie jakiegoś aktu administracji rządowej rozporządzeniem, a aktu organu samorządu terytorialnego uchwała nie wystarcza do przyjęcia, że mamy do czynienia z aktem prawa miejscowego. Niezbędne jest każdorazowo ustalenie, czy dany akt mimo swojej specyfiki przedmiotowej lub podmiotowej i takiego a nie innego stopnia konkretyzacji jest lub nie jest aktem prawa miejscowego. Tak zróżnicowana wewnętrznie sfera prawotwórstwa wymaga też traktowania w sposób odrębny każdego rodzaju aktu prawa miejscowego przy badaniu, czy mieści się on w wymogach związanych z aktami normatywnym"13. Watpliwości w tym zakresie budzi wiele typów uchwał, m.in. o utworzeniu zakładu budżetowego czy też o nadaniu nazwy ulicy. Czy stanowią one akty prawa miejscowego czy też nie? ${ }^{14}$

Aby udzielić jednoznacznej odpowiedzi, należałoby - posiłkując się dorobkiem doktryny - skonstruować ich definicję. Pierwszą niepełną definicję legalną prawa miejscowego można odnaleźć w ustawie z 20 lipca 1983 r. o systemie rad narodowych i samorządzie terytorialnym ${ }^{15}-\mathrm{w}$ rozdz. 6 zatytułowanym „Prawo miejscowe”. Z kolei w art. 40 ust. 1 ustawy z 8 marca 1990 r. o samorządzie terytorialnym ${ }^{16}$ określało się przepisy powszechnie obowiązujące sta-

11 Dolnicki (2018a): 297-299.

12 Makowski (2012): 293.

13 Wyrok TK z 6 października 2004 r., SK 42/02.

14 Dolnicki (2009): 214.

15 Ustawa z 20 lipca 1983 r. o systemie rad narodowych i samorządzie terytorialnym, Dz. U. Nr 41, poz. 185.

16 Ustawa o samorządzie terytorialnym z 8 marca 1990 r., Dz. U. Nr 16, poz. 95. 
nowione przez organy samorządu mianem „przepisów gminnych”. Przepisy powszechnie obowiązujące wydawane przez wojewodów w drodze rozporządzeń nazywano natomiast przepisami miejscowymi. Obecnie terminologia prawa miejscowego została ujednolicona i dostosowana do nazewnictwa ustalonego w art. 87 Konstytucji RP. Wszystkie trzy ustawy samorządowe oraz ustawa o wojewodzie i administracji rządowej w województwie ${ }^{17}$ zawierają odpowiednie rozdziały odnoszące się do aktów prawa miejscowego stanowionego przez regulowane w nich organy. „Niestety żaden z [...] aktów normatywnych nie daje wystarczających argumentów, aby podać wyczerpujaccą definicję prawa miejscowego" 18 .

Mimo że ustawodawca nie zdefiniował jednoznacznie aktu prawa miejscowego, nie wskazał też enumeratywnie wyczerpującego katalogu takich aktów, to jednak w wielu przepisach prawa materialnego wyraźnie wskazuje się, czy konkretny akt będzie miał charakter aktu prawa miejscowego czy też nie. W przypadku gmin do tej grupy zaliczyć można m.in.: miejscowy plan zagospodarowania przestrzennego, miejscowy plan odbudowy obiektów budowlanych, regulamin dostarczania wody i odprowadzania ścieków czy też regulamin utrzymania czystości i porządku na terenie gminy ${ }^{19}$.

\section{UCHWALA JAKO FORMA WYPOWIEDZI ORGANU JEDNOSTKI SAMORZĄDU TERYTORIALNEGO}

Samo pojęcie uchwały nie ma swojej definicji legalnej. W ugruntowanych poglądach doktryny wskazuje się jednak, że tego rodzaju forma prawna stanowi po prostu wyraz woli organu kolegialnego wieloosobowym składzie ${ }^{20}$. Jego członkowie składają - każdy z osobna - oświadczenie woli, a uchwała jest wypadkową tych oświadczeń, powstała zgodnie z obowiąujacymi przepisami ${ }^{21}$. $\mathrm{W}$ warunkach samorządowych to rada gminy, rada powiatu oraz sejmik województwa, jako organy jednostek samorządu terytorialnego, podejmuja aktywność prawodawczą przez podejmowanie uchwał ${ }^{22}$. Uchwała podejmowana jest w trakcie posiedzenia (sesji) w drodze głosowania, a jej celem jest rozstrzygnięcie określonej sprawy lokalnej o charakterze publicznym ${ }^{23}$. Uchwała będąca aktem prawa miejscowego musi opierać się i mieścić w granicach ustawowego upoważnienia oraz zostać prawidłowo ogłoszona. Należy zaznaczyć, że uchwała niebędąca aktem prawa miejscowego może zaś mieć podstawę w prawie wewnętrznym (w takim przypadku wystarczy ogólna norma kompetencyjna da-

17 Ustawa o wojewodzie i administracji rządowej w województwie z 23 stycznia 2009 r., t.jedn.: Dz. U. 2019, poz. 1464.

18 Bułajewski (2012): 6.

19 Czerw (2008): 144.

${ }^{20}$ Chróścielewski (1994): 135.

21 Szewc (2007): 85.

22 Zimmermann (2016): 291.

23 Wiktorowska (2017): 250. 
nego organu). Uchwała tego typu nie musi mieć charakteru normatywnego, nie jest również konieczne jej ogłoszenie. Przykładem może być apel czy deklaracja, które przybierają formę uchwały, wyrażając stanowisko organu kolegialnego, jednak nie stanowią one aktów prawa miejscowego. Pogląd taki znajduje potwierdzenie w orzecznictwie: „Ani ustrojodawca, ani ustawodawca, nie zakazał organom stanowiącym jednostek samorząu terytorialnego, umieszczania $\mathrm{w}$ statutach podstaw do występowania z apelem czy deklaracją. Uchwała jest nie jedyna, lecz główną formą uzewnętrzniania woli rady. W praktyce organ stanowiący podejmuje także apele, wnioski, rezolucje, stanowiska itp. Statut gminy stanowi wystarczająca podstawę do podjęcia uchwały. Apel bądź deklaracja nie musi dotyczyć wyłącznie spraw publicznych o znaczeniu lokalnym, nie zastrzeżonych ustawami na rzecz innych podmiotów [...] - w przeciwieństwie do działań władczych, które muszą być oparte na normach prawa materialnego" ${ }^{24}$.

W odniesieniu do wszystkich trzech stopni samorządu głosowania jawne nad uchwałami odbywają się za pomocą urządzeń umożliwiających sporządzenie i utrwalenie imiennego wykazu głosowań radnych, chyba że nie jest to możliwe z przyczyn technicznych, wówczas przeprowadza się głosowanie imienne. Aby zapewnić przejrzystość i jawność sprawowania władzy, imienne wykazy głosowań podaje się niezwłocznie do publicznej wiadomości w Biuletynie Informacji Publicznej i na stronie internetowej jednostki oraz w inny sposób zwyczajowo przyjęty na danym obszarze. W przeciwieństwie do organów kolegialnych, organy monokratyczne (jednoosobowe) wydają zarządzenia ${ }^{25}$.

Uważa się, że uchwała nie jest jedyną formą, w jakiej organ stanowiący jednostki samorządu terytorialnego może dać wyraz swojemu stanowisku ${ }^{26}$. Do katalogu form takich wypowiedzi zalicza się ponadto m.in.: deklaracje, apele, opinie, oświadczenia, listy intencyjne, protesty, rezolucje. Warto jednak zwrócić uwagę na zasadniczą różnicę pomiędzy uchwałą a innymi wskazanymi formami. To uchwała stanowi formę wskazana przez ustawodawcę jako właściwą do realizacji ustawowych kompetencji jednostek, wynikających z przepisów prawa ustrojowego oraz materialnego prawa administracyjnego. Co więcej, tylko uchwała obligatoryjnie musi posiadać podstawę prawna, tj. delegację do uregulowania konkretnych zagadnień w prawie miejscowym, inne wskazane akty - niekoniecznie ${ }^{27}$.

\section{PRAWO POWSZECHNIE OBOWIĄZUJĄCE A PRAWO WEWNĘTRZNE}

Akty normatywne stanowione przez organy jednostek samorządu terytorialnego można podzielić na akty powszechnie obowiązujące, będące aktami prawa miejscowego, oraz akty wewnętrze, niemające takiego charakteru.

\footnotetext{
24 Por. wyrok NSA z 25 kwietnia 2017 r., I OSK 121/17.

25 Szewc, Szewc (1999): 43.

26 Koc (2013): 48.

27 Cybulska, Wierzbica (2011): 87-89.
} 
Uznanie danej uchwały za akt prawa miejscowego pociaga za sobą istotne skutki, a ponadto wiąże się $\mathrm{z}$ obowiązkiem jej publikacji $\mathrm{w}$ wojewódzkim dzienniku urzędowym. Nieprawidłowe zakwalifikowanie aktu może mieć poważne konsekwencje, m.in. skutkować nieważnością uchwały. Akty powszechnie obowiąujące odnoszą się do podmiotów zewnętrznych (tj. obywateli - osób fizycznych, ale także osób prawnych i jednostek nieposiadających osobowości prawnej). Akty wewnętrzne w odróżnieniu od nich dotyczą podmiotów podporządkowanych organizacyjnie lub służbowo organom je stanowiącym. W doktrynie dominuje pogląd, że o normatywnym charakterze aktu prawa miejscowego przesądza sposób określenia jego adresata. Co ciekawe, „generalność” $\mathrm{w}$ tym zakresie niekoniecznie oznacza liczbę mnoga, nieważna jest bowiem faktyczna liczba adresatów. Ważny jest za to fakt powtarzalności jego zastosowania w każdej sytuacji spełniajacej określone kryteria ${ }^{28}$.

Problemy związane z klasyfikacją poszczególnych aktów tworzonych przez prawodawcę lokalnego od dawna sa sygnalizowane w doktrynie prawa administracyjnego. Autorzy zajmujacy się tym zagadnieniem wypracowali nawet termin „przypadek graniczny” - na określenie aktów, co do których istnieje w tym zakresie szereg uzasadnionych wątpliwości ${ }^{29}$.

Akty prawa miejscowego, będąc źródłem prawa powszechnie obowiązującego, są zarazem aktami normatywnymi. Te zaś akty charakteryzują się następującymi cechami:

(1) oznaczenie adresata norm prawnych pozostającego poza strukturą administracji - jako źródło prawa powszechnie obowiązującego mogą regulować postępowanie wszystkich kategorii adresatów (obywateli, organów, organizacji publicznych i prywatnych, przedsiębiorców). Są więc prawem dla wszystkich, którzy znajdą się w przewidzianej przez nie sytuacji. W praktyce oznacza to, że ich adresatami są nie tylko osoby będące mieszkańcami danej jednostki, lecz także te, które przebywają na jej terenie;

(2) terytorialny zasięg - obowiązują tylko na obszarze działania organów, które je ustanowiły. Często ich zasięg pokrywa się z obszarem danej jednostki samorządu terytorialnego, ale mogą być także stanowione dla mniejszych obszarów;

(3) normatywny charakter - zawierają wypowiedzi wyznaczające adresatom pewien sposób zachowania się (nakazy, zakazy, uprawnienia);

(4) generalny i abstrakcyjnych charakter norm prawnych - charakter generalny mają te normy, które definiuja adresatów przez wskazanie ich cech, a niewymienienie z nazwy, abstrakcyjność normy natomiast wyraża się w tym, że nakazywane, zakazywane lub dozwolone zachowanie ma zachodzić w pewnych, z reguły powtarzalnych okolicznościach, a nie w jednej konkretnej sytuacji. Muszą być powtarzalne, nie mogą więc konsumować się przez jednorazowe zastosowanie ${ }^{30}$.

\footnotetext{
28 Jaworska-Dębska (2009): 440.

${ }^{29}$ Chróścielewski (1994): 83-98.

${ }^{30}$ Wyrok WSA w Olsztynie z 27 kwietnia 2017 r., II SA/Ol 245/17.
} 
Dorota Dabek dodaje do tej listy jeszcze trzy cechy, tj.:

(5) wykonawczy charakter;

(6) brak możliwości regulowania spraw należących do „materii ustawowej”;

(7) związanie ramami stworzonymi przez ustawy ${ }^{31}$.

Warunkiem wydania aktu prawa miejscowego, podobnie jak rozporządzenia, jest delegacja ustawowa, czyli konkretna norma zawarta w ustawie zwykłej, upoważniająca dany organ samorządu terytorialnego do ustanowienia aktu normatywnego. Artykuł 94 Konstytucji RP stanowi, że: „Zasady i tryb wydawania tych aktów określa ustawa”. Przywołany przepis wskazuje na szerszy niż w przypadku rozporządzenia zakres swobody lokalnego prawodawcy $^{32}$. Przywołana w Konstytucji RP ustawa jest w rzeczywistości grupa ustaw, które po części regulują to zagadnienie (są to m.in. samorządowe ustawy ustrojowe, ustawa o wojewodzie i administracji rządowej w województwie oraz ustawa o ogłaszaniu aktów normatywnych i niektórych innych aktów prawnych $\left.^{33}\right)$.

Wątpliwości te wielokrotnie były przedmiotem rozstrzygnięć sądów administracyjnych. Dla przykładu, w wyroku NSA z 18 lipca 2006 r. wskazano, iż „dla kwalifikacji danego aktu jako aktu prawa miejscowego znaczenie decydujące ma charakter norm prawnych i kształtowanie przez te normy sytuacji prawnej adresatów. W przypadku bowiem uznania, że uchwała ta zawiera przynajmniej jedną normę postępowania o charakterze generalnym i abstrakcyjnym byłaby ona aktem prawa miejscowego, który [...] podlegałby obowiązkowi publikacji w Dzienniku Urzędowym Województwa"34.

Warto wskazać, że w ostatnich latach zrodziła się nowa, odrębna grupa aktów prawa miejscowego - indywidualne akty normatywne. Potwierdza to linia orzecznicza TK (m.in. rozporządzenie o utworzeniu zwiąku metropolitalnego w województwie śląskim oraz o zmianie jego granic ${ }^{35} \mathrm{i}$ in. ${ }^{36}$.

\section{INNE ŹRÓDŁA PRAWA MIEJSCOWEGO}

Do innych, odmiennych od powszechnie obowiąujących, źródeł prawa miejscowego zaliczyć można tzw. swoiste źródła prawa ${ }^{37}$. W tej grupie znajduja się m.in.: (1) akty prawa wewnętrznego; (2) akty planowania; (3) normy techniczne, a także po części (4) orzecznictwo sądów. Jednak w odróżnieniu od źródeł prawa powszechnie obowiązującego, których katalog jest zamknięty,

${ }^{31}$ Dabek (2004): 70-75.

${ }^{32}$ Dolnicki (2018b): 19.

${ }^{33}$ Ustawa o ogłaszaniu aktów normatywnych i niektórych innych aktów prawnych z 20 lipca 2000 r., t.jedn.: Dz. U. 2019, poz. 1461.

${ }^{34}$ Wyrok NSA z 18 lipca 2006 r., I OSK 669/06.

${ }^{35} \mathrm{Na}$ podstawie art. 4 ust. 1 pkt 1 ustawy z 9 marca 2017 r. o związku metropolitalnym w województwie śląskim, Dz. U. 2017, poz. 730.

${ }^{36}$ Dolnicki (2018b): 17-18.

${ }^{37}$ Ochendowski (2006): 137. 
Konstytucja RP nie zawiera enumeratywnego wyliczenia źródeł prawa wewnętrznego. Wymienia tylko w art. 93 ust. 1 dwa ich rodzaje: uchwały i zarządzenia $^{38}$, dopracowując, że chodzi o uchwały Rady Ministrów oraz że zarządzenia Prezesa Rady Ministrów i ministrów mają charakter wewnętrzny i obowiązuja tylko jednostki organizacyjnie podległe organowi wydającemu te akty.

Problem prawa wewnętrznego jest niezwykle złożony. Jednak nie ulega wątpliwości, że kryterium rozróżnienia tego rodzaju aktów od aktów powszechnie obowiązujących stanowi określenie adresata norm prawnych w nich zawartych. Akty wewnętrzne są skierowane do jednostek organizacyjnych (oraz ich użytkowników i pracowników), podporządkowanych organowi wydającemu dany akt organizacyjnie lub służbowo. Będą to więc w przypadku gminnych jednostek np. uczniowie i nauczyciele szkół, pacjenci przychodni czy też osoby korzystające z obiektów sportowo-rekreacyjnych. Ponieważ przepisy wewnętrzne nie reguluja praw i obowiązków obywateli, nie ma co do nich zastosowania domniemanie powszechnej znajomości prawa oraz obowiązek publikacji w organach promulgacyjnych, wystarczy tylko, że dotrą do odpowiednich adresatów ${ }^{39}$.

Aktami prawa wewnętrznego moga być uchwały organów kolegialnych lub zarządzania organów monokratycznych. Wśród nich należy wskazać: regulaminy, instrukcje, pisma okólne i wiele innych. Uchwała niebędąca aktem prawa miejscowego jest aktem prawa wewnętrznego (tzw. akt kierownictwa wewnętrznego bądź też akt wewnętrznie obowiązujący) ${ }^{40} \mathrm{i}$ jako taka wchodzi w życie z chwilą podjęcia. Następnie zostaje podana do publicznej wiadomości, na ogół za pośrednictwem Biuletynu Informacji Publicznej, co wypełnia przesłankę dotarcia z jej treścią do odpowiednich adresatów ${ }^{41}$. Należy jednak zaznaczyć, że nie wszystkie akty prawa wewnętrznego są w ten sposób publikowane. „Istotna różnica pomiędzy aktem normatywnym stanowiącym akt prawa miejscowego a aktem kierownictwa wewnętrznego sprowadza się do tego, że akt prawa miejscowego rozstrzyga w sposób bezwzględny o prawach i obowiązkach podmiotów tworzących wspólnotę samorządowa, natomiast akt kierownictwa wewnętrznego określa jedynie zadania, organizację oraz obowiązki osób i jednostek organizacyjnych gminy"42.

Odrębną kategorię stanowią tzw. akty planowania, czyli różnego rodzaju strategie, plany i programy. Również ich charakteru prawnego nie sposób jednoznacznie określić. Niektóre mają moc powszechnie obowiąująca, a inne nie $^{43}$. Planowanie $\mathrm{w}$ prawie administracyjnym wiąże się $\mathrm{z}$ określaniem celów i środków działania administracji publicznej w sferze wyznaczonej przez jej zadania i kompetencje ${ }^{44}$. W literaturze wskazuje się, że planowanie jest „procesem, ciagiem działań faktycznych i prawnych, sprowadzającym się do

\footnotetext{
38 Dąbek (2003): 67.

39 Ochendowski (2006): 137-139.

40 Bonusiak (2018): 45.

${ }^{41}$ Adamczyk (2013): 29.

42 Wyrok WSA we Wrocławiu z 20 stycznia 2010 r., IV SA/Wr/420/09.

43 Ochendowski (2006): 141-142.

${ }^{44}$ Gajewski (2017): 23.
} 
ustalenia celów mających być przedmiotem przyszłych dążeń administracji publicznej" ${ }^{45}$.

Plany czy programy nie stanowią na ogół aktów prawa miejscowego, jako że ich adresatem jest sama jednostka, która je wydała (tj. w przypadku samorządu - gmina, powiat czy województwo), a nie podmioty będące na zewnętrz administracji ${ }^{46}$. Maja one oczywiście bardzo istotne znaczenie, jednak o charakterze kierunkowym, nie konkretyzuja bowiem żadnych uprawnień lub obowiązków podmiotów spoza systemu administracji. Jako dokumenty staja się instrumentami, za pomoca których realizowany jest wymóg zaplanowania przyczyn, treści i konsekwencji decyzji przed ich podjęciem. Służą więc do przemyślanego i uwzględniającego wszelkie możliwości techniczne, organizacyjne czy finansowe działania administracji publicznej. Wspierają tym samym proces organizowania, czyli harmonizacji działań i zasobów ${ }^{47}$.

W tej grupie, na stopniu samorządowym, ważną rolę pełnią przede wszystkim corocznie uchwalane budżety, a z punktu widzenia polityki długofalowejstrategie rozwoju lokalnego i regionalnego, studia uwarunkowań i kierunków zagospodarowania przestrzennego oraz miejscowe plany zagospodarowania przestrzennego, których rzetelne przygotowanie i uchwalenie jest jednym z podstawowych narzędzi kierowania rozwojem danej jednostki. Akty planowania $\mathrm{w}$ gminie powinny być spójne z podobnymi planami na stopniu powiatowym, wojewódzkim, krajowym czy międzynarodowym. Nie ma tutaj zasadniczo mowy o formalnej hierarchii, jednak przewidziany w przepisach system różnego rodzaju opinii i uzgodnień pomiędzy poszczególnymi jednostkami różnych stopni zabezpiecza spójność przyjmowanych dokumentów. Tylko wówczas realizacja poszczególnych celów wspiera osiaganie szerszych rezultatów i wykorzystując efekt synergii, przyczynia się do spójności społecznej i gospodarczej na jak największą skalę ${ }^{48}$.

Treści planów i programów mające charakter prognoz, analiz czy zasad polityki, jaka mają prowadzić organy wykonawcze, nie maja charakteru normatywnego, a wręcz przeciwnie, stanowia jedynie wytyczne i kierunki dzia$ł n^{49}$. Akty planowania nie stanowią osobnej kategorii działań administracyjnych. Moga przybierać postać aktów normatywnych, zarówno generalnych, jak i indywidualnych, a także czynności materialno-technicznych czy też działalności społeczno-organizatorskiej. Niejednolita jest także ich możliwa forma i charakter prawny. Niektóre mają postać ustawy lub rozporządzenia, inne zarządzenia, uchwały bądź decyzji administracyjnej ${ }^{50}$. Oczywiście nie dotyczy to aktów prawnych, dla których wskazano w przepisach odpowiednią formę (np. uchwała organu stanowiącego).

Należy wspomnieć jeszcze o tzw. aktach samoregulacji, które stały się w ostatnich latach bardzo popularne i stanowią źródło „miękkiego” prawa

\footnotetext{
45 Stasikowski (2009): 29.

46 Żuchowski (2007): 70.

47 Kożuch (2004): 61.

${ }^{48}$ Misiag (2004): 91-93.

49 Wyrok WSA w Białymstoku z 2 lutego 2006 r., II SA/Bk 681/05.

50 Wlaźlak (2009): 25.
} 
w samorządach. Ciekawym przykładem samorządowej samoregulacji będzie kodeks dobrych praktyk, związany ściśle z tzw. prawem do dobrej administracji. W polskim porządku prawnym prawo do dobrej administracji nie zostało wyrażone expressis verbis w ramach najwyższego aktu prawnego w państwie, którym jest Konstytucja RP. Jednak w orzecznictwie TK znajdziemy szereg odniesień do niego, m.in.: „Obowiązki organów władzy publicznej wynikające z konstytucyjnej zasady demokratycznego państwa prawnego oraz z zasady praworządności należy uznać za podstawę i standard dobrej administracji”" ${ }^{1}$. Konstruujac definicję aktów samoregulacyjnych dotyczących standardów dobrej administracji, można więc przyjąć, że jest to „zespół uprawnień przysługujących obywatelowi w stosunkach władczych z organami administracji publicznej i nastawionych na ochronę praw podmiotowych jednostki, a także szerzej: prawidłowości, rzetelności i sprawności postępowań administracyjnych"52.

Dokumentem, który stanowi swoiste źródło i na którym są wzorowane samorządowe kodeksy etyczne, wydaje się - uchwalony 6 września 2001 r. przez Parlament Europejski w formie niewiążącej ${ }^{53}$ rezolucji - Europejski kodeks dobrej administracji ${ }^{54}$. Zawiera on m.in. zasadę praworządności, zasadę niedyskryminacji, zasadę współmierności w sferze osiąnięcia obranego celu, zasadę bezstronności, niezależności i obiektywności, zasadę stosownego terminu podjęcia decyzji oraz wiele innych, których realizacja ma być gwarancją bezstronnego, rzetelnego i szybkiego, a także odbywającego się w atmosferze uprzejmości i życzliwości, załatwiania spraw administracyjnych przez obywateli. Ponadto w 2007 r. w formie zalecenia Kodeks dobrej administracji uchwalił też Komitet Ministrów Rady Europy ${ }^{55}$. Prawo do dobrej administracji na arenie europejskiej wyrażone jest też w Karcie praw podstawowych Unii Europejskiej ${ }^{56}$, w rozdziale dotyczacym praw obywatelskich (art. 41 KPP UE). Dokument ten stanowi zbiór fundamentalnych praw człowieka, ale także i obowiązków obywatelskich, któremu moc wiążącą nadano w Traktacie lizbońskim. Jeśli chodzi o dokumenty krajowe, to dla przykładu, zasady etyki korpusu służby cywilnej określone zostały zarządzeniem Prezesa Rady Ministrów z 6 października 2011 r. ${ }^{57}$ Wśród wskazanych w nim są m.in.: zasada godnego zachowania, zasada służby publicznej, zasada lojalności, zasada neutralności politycznej, zasada bezstronności czy też zasada rzetelności. Również

51 Wyrok TK z 18 grudnia 2007 r., SK 54/05.

52 Sześciło (2014): 95.

${ }^{53}$ W wyroku NSA w Warszawie z 27 maja 2008 r., I OSK 867/07 wskazano, iż: „Europejski Kodeks Dobrej Administracji nie jest aktem wiążącymi w Polsce, może być jedynie traktowany jako akt wytyczający pożądane standardy działania administracji”.

${ }_{54}$ Europejski kodeks dobrej administracji (European Code of Good Administrative Behavior), Dz. Urz. UE C 72 E z 21 marca 2002 r.

55 Zalecenie R(2007)7 Komitetu Ministrów Rady Europy z 20 czerwca 2007 r. dla państw członkowskich w sprawie dobrej administracji (Kodeks Dobrej Administracji).

${ }^{56}$ Karta praw podstawowych Unii Europejskiej (2010/C 83/02) (dalej jako: KPP UE).

57 Zarządzenie nr 7 Prezesa Rady Ministrów w sprawie wytycznych w zakresie przestrzegania zasad służby cywilnej oraz w sprawie zasad etyki korpusu służby cywilnej z 6 października 2011 r. (M.P. nr 93, poz. 953). 
ustawa o pracownikach samorządowych ${ }^{58}$ zawiera odniesienia do reguł dobrej administracji. W art. 24 u.p.s., gdzie ustawodawca umieścił katalog podstawowych obowiązków pracowniczych, wskazano, że pracownik samorządowy ma wykonywać swoje zadania sumiennie, sprawnie i bezstronnie, a także uprzejmie i życzliwie.

Mimo że pracownicy lokalnej administracji publicznej, generalnie - jako grupa, podlegaja szeregowi reguł etycznych, wiele jednostek decyduje się na uchwalenie własnych, wewnętrznych kodeksów. Tego typu samoregulacje zalicza się do grupy quasi-władczej, głównie z uwagi na ograniczony i ściśle określony katalog adresatów. Zebrane w nich reguły nie są formalnie wiążące, mają jednak na celu wskazanie i upowszechnienie modelu odpowiedniego działania w danej sferze. Narzędzia samoregulacyjne obejmują nie tylko wspomniane już kodeksy postępowania, lecz także polityki, wskaźniki, mierzalne zobowiązania, certyfikaty dla podmiotów spełniających określone wymagania czy jasne zasady kontroli realizacji przyjętych zobowiązań ${ }^{59}$. Wprowadzają one standardy postępowania w sytuacjach, które nie zostały scharakteryzowane w prawie powszechnie obowiązującym. O ile bowiem korupcja czy nadużywanie służbowych uprawnień wypełniają znamiona czynów zabronionych, o tyle już nieżyczliwość w kontaktach z obywatelami takich znamion nie wypełnia.

\section{PRZEPISY PORZĄDKOWE}

Z zasady akty prawa miejscowego ustanawia - jeśli ustawa nie obliguje inaczej - rada, co wynika z jej istoty jako organu stanowiącego. Zdarzają się jednak wyjątki, a mianowicie, gdy sprawa ma charakter pilny (jest niecierpiaca zwłoki) i jej rozstrzygnięcie jest niezbędne dla ochrony życia lub zdrowia obywateli oraz dla zapewnienia porządku, spokoju i bezpieczeństwa publicznego (art. 41 ust. 2 u.s.g.) - wówczas w formie przepisów porządkowych może ją uregulować także wójt swoim zarządzeniem ${ }^{60}$. Podobnie w powiecie przepisy porządkowe w przypadkach niecierpiących zwłoki, gdy jest to niezbędne do ochrony życia, zdrowia lub mienia obywateli, ochrony środowiska naturalnego albo do zapewnienia porządku, spokoju i bezpieczeństwa publicznego, o ile przyczyny te występują na obszarze więcej niż jednej gminy - wydaje zarząd (art. 42 ust. 2 u.s.p.). Zarówno w gminie, jak i w powiecie wydane przez organ wykonawczy przepisy porządkowe podlegają zatwierdzeniu na najbliższej sesji rady, tracąc moc w razie nieprzedłożenia ich do zatwierdzenia lub odmowy ich zatwierdzenia przez radę.

Aby wydanie przepisów porządkowych było uzasadnione, muszą zostać spełnione dwie przesłanki: obiektywna i subiektywna. Zgodnie z ta pierwszac materia, która ma być uregulowana w przedmiotowych przepisach, nie może

${ }^{58}$ Ustawa o pracownikach samorządowych z 21 listopada 2008 r., Dz. U. 2018, poz. 1260 (dalej jako: u.p.s.).

${ }^{59}$ Mednis, Sześciło (2014): 91.

${ }^{60}$ Ochendowski (2006): 122-136. 
stanowić przedmiotu regulacji innych przepisów powszechnie obowiązujących. Ustawodawca posługuje się tu zwrotem: „w zakresie nieuregulowanym” (art. 40 ust. 3 u.s.g.). Druga, subiektywna, przesłanka dotyczy uzasadnienia zastosowania przepisów porządkowych, tj. wartości, które mają podlegać dzięki nim ochronie. W przepisach wskazuje się m.in. na bezpieczeństwo, spokój publiczny czy porządek. To organ wydający przepisy musi ocenić zagrożenia i uzasadnić podjęcia działania absolutna „koniecznością”, co jak wynika z analizy rozstrzygnięć organów nadzorczych oraz orzecznictwa sądów administracyjnych - stanowi dla samorząów spore wyzwanie ${ }^{61}$. Zatem dla wydania przepisów porządkowych niezbędne jest, by zaistniała (1) obiektywna luka prawna, a więc brak uregulowania w jakimś zakresie w przepisach powszechnie obowiąujących; (2) zagrożenie jednej ze wskazanych przez ustawodawcę wartości; (3) niezbędność, czyli inaczej mówiąc, konieczność podjęcia działań; (4) przypadek ma mieć cechę niecierpiącego zwłoki, tj. żeby uniknąć uszczerb$\mathrm{ku}$, działania należy podjąć natychmiast.

Podsumowując, przepisy porządkowe nie stanowią przedmiotu bieżącej działalności prawotwórczej jednostek samorządu terytorialnego, mają raczej charakter wyjątkowy, gdyż korzysta się z nich w sytuacjach nadzwyczajnych. Jeszcze rzadziej zaś przepisy te wydają organy wykonawcze ${ }^{62}$.

\section{PODSUMOWANIE}

Szerokie ujęcie źródeł prawa samorządu terytorialnego powoduje, że stanowią one dość obszerną i niejednolita grupę aktów prawnych. Zaliczyć do niej należy nie tylko akty pochodzące od prawodawcy lokalnego, lecz także od podmiotów wobec samorządu zewnętrznych, tj. ustawodawcy, organów władzy wykonawczej, a nawet organizacji międzynarodowych. Co więcej, akty te moga przybierać rozmaite formy, począwszy od umów międzynarodowych, poprzez ustawy i rozporządzenia, a na uchwałach skończywszy. Moga odnosić się do kwestii samorządowych w całości albo jedynie fragmentarycznie, mogą wreszcie mieć charakter powszechnie obowiązujących bądź jedynie wewnętrznych ${ }^{63}$. Ten duży zakres oraz mocne zróżnicowanie źródeł prawa miejscowego wskazuje na istotność podjętej w niniejszym opracowaniu problematyki.

Charakterystyczne dla aktów prawa miejscowego jest to, że identyczne zadania są regulowane i realizowane w odmienny sposób w różnych częściach kraju. Ma to na celu dopasowanie stanowionego prawa do specyfiki uwarunkowań lokalnych, co umożliwia bardziej adekwatne działanie, odpowiadające warunkom danego miejsca, i zarazem wpływa na skuteczność podejmowanych interwencji. Chodzi tu w dużej mierze o wzięcie pod uwagę spraw bardzo szczegółowych, relewantnych jedynie w odniesieniu do konkretnej wspólnoty

\footnotetext{
61 Bohdan (2018): 98-99.

62 Bohdan (2018): 102-104.

${ }^{63}$ Feja-Paszkiewicz (2018): 198.
} 
lokalnej czy regionalnej. Znaczenie ma też racjonalność podziału zadań zgodnie z zasadą pomocniczości, uzupełnienie na bieżąco „luk” w obowiązującym systemie prawnym, szybkość działania, szczegółowość przyjmowanych rozwiazań, motywy administracyjno-techniczne czy wreszcie aspekt aksjologiczny ${ }^{64}$.

Ponadto łatwiej włączyć obywateli i ich organizacje w stanowienie prawa lokalnego, niż miałoby to miejsce $\mathrm{w}$ przypadku prawa krajowego ${ }^{65}$. Akty prawa miejscowego reguluja takie zagadnienia, dla których nie ma potrzeby - z punktu widzenia efektywności - tworzenia unormowań identycznych w skali całego państwa ${ }^{66}$. Argumenty powyższe często pojawiają się w treści rozstrzygnięć nadzorczych, m.in.: „ustawodawca formułując określoną delegację do wydania aktu wykonawczego, przekazuje upoważnienie do uregulowania wyłącznie kwestii nie objętych dotąd żadną normą o charakterze powszechnie obowiązującym w celu ukształtowania stanu prawnego uwzględniającego m.in. specyfikę, możliwości i potrzeby środowiska, do którego właściwy akt wykonawczy jest skierowany" ${ }^{\prime 2}$. Nie zmienia to jednak faktu, że prawo miejscowe stanowi część jednolitego państwowego systemu prawnego, którego podstawą jest Konstytucja $\mathrm{RP}^{68}$.

Władztwo i samodzielność prawodawcza na stopniu samorządowym są wyrazem istotnej roli ustrojowej jednostek samorządu terytorialnego w strukturze zdecentralizowanej administracji publicznej. Mimo że ustrój państwa jest zdecydowanie unitarny i w związku z tym Konstytucja RP nie stwarza gminom, powiatom i województwom możliwości tworzenia odrębnej legislacji, to konstrukcja prawa miejscowego stanowi szansę na wprowadzenie przepisów dostosowanych do lokalnych i regionalnych warunków, potrzeb oraz oczekiwań mieszkańców, uwzględniających ich interesy przy jednoczesnym braku sprzeczności z interesem państwa jako całości.

Adamczyk, A. (2013). Publicznoprawne formy działania administracji. Teoria i praktyka. Warszawa.

Boć, J. (red.) (1998). Konstytucje Rzeczypospolitej oraz komentarz do Konstytucji z 1997 r. Wrocław.

Bohdan, A. (2018). Przepisy gminne porządkowe jako szczególne akty prawa miejscowego, [w:] B. Dolnicki (red.), Źródła prawa w samorządzie terytorialnym. Warszawa: 96-106.

Bonusiak, E. (2018). Uchwała rady gminy o nadaniu nazwy ulicy aktem normatywnym o charakterze generalno-konkretnym? [w:] B. Dolnicki (red.), Źródła prawa w samorządzie terytorialnym. Warszawa: 44-52.

Bułajewski, S. (2012). Pojęcie akty prawa miejscowego w poglądach doktryny, orzecznictwie Trybunału Konstytucyjnego i sądów administracyjnych. Studia Prawnoustrojowe 18: 5-21.

Chróścielewski, W. (1994). Akt administracyjny generalny. Łódź.

Cybulska, R., Wierzbica, A. (2011). Uchwała jako forma wyrażania woli przez organy stanowiące jednostek samorządu terytorialnego, [w:] J. Niczyporuk (red.), Teoria instytucji prawa administracyjnego. Księga pamiątkowa Profesora Jerzego Stefana Langroda. Paryż: 94-107.

${ }^{64}$ Dąbek (2015): 50-52.

${ }_{65}$ Rot, Siarkiewicz (1994): $25 \mathrm{n}$.

${ }^{66}$ Boć (1998): 155.

${ }^{67}$ Rozstrzygnięcie nadzorcze Wojewody Lubelskiego z 14 listopada 2018 r. PN-II.4131.329.2018.

${ }^{68}$ Dąbek (2015): 53. 
Czerw, J. (2018). Oddziaływanie wojewody na akty prawa miejscowego stanowione przez rady gmin - wybrane zagadnienia, [w:] B. Dolnicki (red.), Źródła prawa w samorządzie terytorialnym. Warszawa: 139-151.

Dąbek, D. (2004). Prawo miejscowe samorządu terytorialnego. Bydgoszcz-Kraków.

Dąbek, D. (2014). Prawo miejscowe. Warszawa.

Dolnicki, B. (2009). Akty prawa miejscowego w świetle orzecznictwa, [w:] J. Boć, A. Chajbowicz (red.), Nowe problemy badawcze w teorii prawa administracyjnego. Wrocław: 205-232.

Dolnicki, B. (2018a). Samorząd terytorialny. Warszawa.

Dolnicki, B. (2018b). Wstęp, [w:] B. Dolnicki (red.), Źródła prawa w samorządzie terytorialnym. Warszawa: $17-21$.

Feja-Paszkiewicz, A. (2018), Uchwały określające zasady i tryb przeprowadzania konsultacji z mieszkańcami gminy - zagadnienia formalne, [w:] B. Dolnicki (red.), Źródła prawa w samorządzie terytorialnym. Warszawa: 198-216.

Gajewski, S. (2017). Programy rządowe. Studium administracyjnoprawne. Warszawa.

Jaworska-Dębska, B. (2009). Akty normatywne i akty generalne stosowania prawa, [w:] M. Stahl (red.), Prawo administracyjne. Pojęcia, instytucje, zasady w teorii i orzecznictwie. Warszawa: 440-452.

Kotulski, M. (2001). Akty prawa miejscowego stanowionego przez samorząd terytorialny. Samorząd Terytorialny 11(11): 28-42.

Kożuch, B. (2004). Zarządzanie publiczne w teorii i praktyce polskich organizacji. Warszawa.

Makowski, G. (2012). Obywatelska inicjatywa uchwałodawcza - prawo i praktyka, [w:] A. Olech (red.), Dyktat czy uczestnictwo? Diagnoza partycypacji publicznej w Polsce. Tom 1. Warszawa: 288-305.

Mednis, A., Sześciło, D. (2014). Zarządzanie publiczne przez władztwo. Administracja władcza i jej przeobrażenia, [w:] D. Sześciło (red.), Administracja i zarządzanie publiczne. Nauka o współczesnej administracji. Warszawa: 78-93.

Misiag, W. (2004). Budżet gminy dla praktyków. Wzory i przykłady uchwał. Warszawa.

Nowacka, E. (1997). Samorząd terytorialny w administracji publicznej. Warszawa.

Ochendowski, E. (2006). Prawo administracyjne. Część ogólna. Toruń.

Podgórska-Rykała, J. (2018). Strategia jako główne narzędzie prawno-polityczne zarządzania rozwojem w jednostkach samorządu terytorialnego. Przedsiębiorczość i Zarządzanie 19(11.II): 311-324.

Rot, H., Siarkiewicz, K. (1994). Zasady tworzenia prawa miejscowego. Warszawa.

Stasikowski, R. (2009). O istocie funkcji planistycznej administracji publicznej. Przegląd Prawa Publicznego 5: 23-39.

Sześciło, D. (2014). Prawo do dobrej administracji - narzędzie ochrony jednostki przed nadużyciem władztwa, [w:] D. Sześciło (red.), Administracja i zarządzanie publiczne. Nauka o współczesnej administracji. Warszawa: 94-111.

Szewc, A., Szewc, T. (1999). Uchwałodawcza działalność jednostek samorządu terytorialnego. Warszawa.

Szewc, T. (2007). Nazewnictwo form aktów prawa miejscowego. Ruch Prawniczy, Ekonomiczny i Socjologiczny 69(2): 81-91.

Wiktorowska, A. (2017). Samorząd terytorialny, [w:] M. Wierzbowski (red.), Prawo administracyjne. Warszawa: 211-243.

Wlaźlak, K. (2009). Charakter prawny aktów planowania i ich rola w realizacji zadań administracji publicznej. Przegląd Prawa Publicznego 6: 22-24.

Zimmermann, J. (2016). Prawo administracyjne. Warszawa.

Żuchowski, W. (2007). Prawotwórcza działalność samorządu terytorialnego w gospodarowaniu zasobem mieszkaniowym gminy. Samorząd Terytorialny 17(4): 66-71. 


\section{LAW-MAKING AUTONOMY OF LOCAL SELF-GOVERNMENT UNITS}

\section{Sum mary}

The purpose of this paper is to highlight the essence of the lawmaking autonomy of local selfgovernment units, to describe the various legal forms that their formal decisions take, as well as to distinguish and define - using the achievements of the doctrine and jurisprudence - the various categories of acts created by local government bodies. The research method used was based on comparative legal analysis and literature research, evaluation of the legal status existing in the field of the discussed issues, as well as on an analysis of views presented in the science of administrative law and in the case law. The author points out that the legislator has granted local self-government bodies a large degree of law-making independence. Its sources can be found in the Constitution of the Republic of Poland, and then in local government system acts. These norms are additionally strengthened by the provisions of the European Charter of Local SelfGovernment, which provide for the right of local communities to act freely on their territory while respecting the principle of legalism. The attribution of the quality of autonomy to local government units has also been consolidated in the jurisprudence of the Constitutional Tribunal. The far-reaching independence of self-governments can be seen in many areas of their activity, but legislation seems to be one of the most important. Legal acts set the norms and rules of conduct, binding certain groups of addressees and affect their personal situation. in terms of their rights and obligations.

Keywords: local self-government; local law; act of local law 